\title{
Assessment of Host (Corylus sp.) Resistance to Eastern Filbert Blight in New Jersey
}

\author{
John M. Capik and Thomas J. Molnar ${ }^{1}$ \\ Department of Plant Biology and Pathology, Foran Hall, 59 Dudley Road, Rutgers University, New \\ Brunswick, NJ 08901
}

\begin{abstract}
AdDitional INDEX WORDs. hazelnut, tree breeding, disease resistance, germplasm evaluation, nut crops
Abstract. One hundred ninety clonal accessions of Corylus, including species and various interspecific hybrids of $C$. avellana, $C$. americana, $C$. heterophylla, $C$. colurna, and $C$. fargesii, were assessed for their response to field exposure to the eastern filbert blight (EFB) pathogen, Anisogramma anomala, in New Jersey, where the fungus is native. Plants were obtained from the U.S. Department of Agriculture Agricultural Research Service National Clonal Germplasm Repository and Oregon State University, the University of Nebraska, Lincoln, and the National Arbor Day Foundation. Additional plant material was acquired from the Morris and Holden Arboreta and from private nurseries in Amherst, NY, and Niagara-on-the-Lake, Ontario, Canada. The accessions were chosen based on their resistance to EFB in Oregon, a region where $A$. anomala is not native, or anecdotal reports and grower observations of tolerance or resistance to the disease. Trees were planted in the field from 2002 through 2009 in New Jersey where they were exposed to EFB yearly through field inoculations and natural spread. In Jan. 2012, they were visually evaluated for the presence of EFB. The cankers were measured, and the proportion of diseased wood was calculated for susceptible trees. Nearly all accessions reported to be resistant to EFB in Oregon maintained at least a useful level of tolerance in New Jersey with a number remaining free of cankers. However, several accessions developed small to medium-sized cankers and showed branch dieback, including offspring of $C$. avellana 'Gasaway'. Most $C$. americana and $C$. heterophylla accessions remained free of EFB, although variation in EFB response was found in hybrids of these species with $C$. avellana, ranging from no signs or symptoms to severe EFB. Nearly half of the $C$. colurna $\times$ $C$. avellana hybrids developed cankers, whereas each of the $C$. fargesii accessions and most grower selections developed in eastern North America remained free of EFB. The results document the existence of a wide diversity of Corylus germplasm that expresses resistance or a high level of tolerance to EFB in New Jersey and confirms previous reports that $C$. americana is highly resistant to the disease. Interestingly, most $C$. heterophylla and the $C$. fargesii were also found to be resistant despite originating in Asia where $A$. anomala has not been found. The various interspecific hybrids show the potential for incorporating EFB resistance from wild species through breeding. The results provide further evidence of differences in disease expression in Oregon and New Jersey, where isolates differ and disease pressure may be higher.
\end{abstract}

The genus Corylus represents a diverse group of temperate woody plants, all of which produce edible nuts. The genus comprises anywhere from nine to 25 species depending on the taxonomic study with current revisions suggesting 11 to 13 polymorphic species assigned to four subsections (Erdogan, 1999; Erdogan and Mehlenbacher, 2000a, 2000b; Thompson et al., 1996). In the genus, C. avellana is of the greatest economic importance as a result of its large nuts and high-quality kernels. Commercial production is currently restricted to regions with moderate, Mediterranean-like climates, despite having a very wide native range with a northern limit that extends from latitude $68^{\circ} \mathrm{N}$ in Norway to Helsinki to the Ural Mountains (Mehlenbacher, 1991). Turkey produces $\approx 70 \%$ of the world's crop, totaling $888,328 \mathrm{Mg}$ in 2010 [Food and Agriculture Organization of the United Nations (FAO), 2012]. Turkey is followed by Italy, which produces $\approx 15 \%$ of the total,

Received for publication 28 Feb. 2012. Accepted for publication 18 Apr. 2012. Funding for this research comes from the New Jersey Agricultural Experiment Station, the Rutgers Center for Turfgrass Science, and U.S. Department of Agriculture Specialty Crops Research Initiative Competitive Grant 200951181-06028.

We thank C.R. Funk, A. Morgan, C. Leadbetter, A. Novi, S. Mehlenbacher, D. Smith, J. Gordon, E. Grimo, and the USDA-ARS National Clonal Germplasm Repository in Corvallis, OR, for their technical assistance and contribution of plant material.

${ }^{1}$ Corresponding author. E-mail: molnar@aesop.rutgers.edu. and the United States, which is responsible for 3\% to 5\%. Other countries growing noteworthy crops include Azerbaijan, Spain, Georgia, Iran, France, and China (FAO, 2012). Ninety-nine percent of the U.S. crop is produced in the Willamette Valley of Oregon (Mehlenbacher and Olsen, 1997).

European hazelnut production has been attempted in the eastern United States since colonial times. However, the relatively cold climate - and more significantly, an endemic disease called EFB caused by Anisogramma anomala - made these attempts futile (Halsted, 1892; Morris, 1915, 1920; Thompson et al., 1996). The fungus, an obligate, biotrophic ascomycete in the order Diaporthales, infects only plants of Corylus. It is native to the eastern half of North America, associated with its natural host $C$. americana, on which it has been reported to cause only minor damage (Fuller, 1908; Weschcke, 1954). However, the disease causes severe perennial cankers that lead to branch dieback and eventual death of nearly all commercially important cultivars of C. avellana within 4 to 8 years of exposure (Johnson and Pinkerton, 2002; Pinkerton et al., 1993). The causal fungus, whose ascospores penetrate actively growing shoot tips in the spring during periods of rain, expresses no disease symptoms in the host plant in the first year of infection. It is only after the host plant cycles through a period of chilling and dormancy that the cankers erupt in the bark of stems with conspicuous, football-shaped stromata visible by late summer (Johnson and Pinkerton, 2002). 
Efforts began in the early 1900s to develop better-adapted, disease-resistant hazelnuts for the eastern United States through hybridizing $C$. americana with $C$. avellana. This work was pioneered by the nurseryman J.F. Jones of Lancaster, PA, and was continued by C.A. Reed of the U.S. Department of Agriculture (USDA) at Beltsville, MD, and G.H. Slate of the New York Agricultural Experiment Station in Geneva, NY. Their breeding strategies were similar as they hybridized various $C$. avellana cultivars with $C$. americana 'Rush', a wild hazelnut selected in southeastern Pennsylvania (Crane et al., 1937; Molnar, 2011; Reed, 1936; Slate, 1961; Thompson et al., 1996). Although these early breeding efforts used only a narrow germplasm base and were discontinued before commercially viable cultivars were developed, progress was made in combining EFB resistance, cold-hardiness, and improved nut size. Some of the resulting hybrid plants remain available today from private nurseries and many are also held in the USDA, Agricultural Research Service National Clonal Germplasm Repository (NCGR) in Corvallis, OR (USDA, 2011). Furthermore, grower reports in the East suggest a number of selections related to $C$. americana 'Rush' have remained free of EFB over many decades of exposure, supporting a realistic potential to breed hazelnut plants adapted to colder regions that express durable EFB resistance. Fortunately, private breeders and nurserymen in Wisconsin (Weschcke, 1954), Minnesota (Rutter, 1987), Michigan (Farris, 2000), and New York (Gordon, 1993) as well as British Columbia (Gellatly, 1964, 1966) and Ontario (Grimo, 2011), Canada, expanded on the early attempts to develop better adapted, EFB-resistant hazelnuts. The results of their efforts have contributed to the genetic resources currently available for breeding with several private individuals still actively working toward this goal.

The lack of EFB west of the Rocky Mountains and a more amenable climate provided the environment for commercial hazelnut production to thrive in Washington and Oregon since its establishment in the late 1800s (Thompson et al., 1996). However, this scenario changed dramatically with the inadvertent introduction of $A$. anomala into southwestern Washington in the 1960s (Davison and Davidson, 1973). Since that time, EFB has eliminated much of the production in Washington and has subsequently spread throughout the Willamette Valley of Oregon, where its control (scouting for cankers, pruning, and application of fungicides) significantly increases production costs (Johnson et al., 1996; Julian et al., 2008, 2009). Because control methods are not $100 \%$ effective and hazelnuts are traditionally a low-input crop, genetic resistance would be the most economical, long-term means for disease management. In 1975, C. avellana 'Gasaway', an obsolete pollenizer, was discovered to be free of EFB in the middle of a heavily infected orchard of 'DuChilly' in Washington (Cameron, 1976). Despite its low yields of tiny, poor-quality nuts, 'Gasaway', in crosses with susceptible selections, transmits resistance to half of its offspring, suggesting that it is heterozygous for a dominant resistance allele at a single locus (Mehlenbacher et al., 1991, 2004). Since its discovery, 'Gasaway' has been used extensively in breeding efforts at Oregon State University (OSU), culminating after more than 30 years in the release of the improved, EFBresistant nut-producing cultivars Santiam, Yamhill, and Jefferson and several EFB-resistant pollenizers (Mehlenbacher et al., 2007, 2009, 2011; Mehlenbacher and Smith, 2004). They can be grown without fungicides and are predicted to significantly reduce production costs in Oregon (Julian et al., 2009). The ability to grow EFB-resistant cultivars, which have also been selected for improved nut quality and yields, is leading to an expansion and reinvigoration of the Oregon hazelnut industry after several decades of decline (S.A. Mehlenbacher, personal communication).

Because of concern about the long-term durability of a single gene for resistance, research at OSU included screening many hundreds of plants held in their germplasm collections and that of the NCGR for their response to inoculations with $A$. anomala. Although most plants were highly susceptible, the work at OSU, spanning more than two decades, identified a number of new EFB-resistant $C$. avellana accessions from a diversity of origins as well as resistant accessions of other Corylus species and interspecific hybrids, several of which are now being incorporated into breeding efforts (Chen et al., 2005, 2007; Coyne et al., 1998; Lunde et al., 2000; Sathuvalli et al., 2010, 2011a). Complicating the situation, however, is that plants identified as resistant in Oregon were challenged only with isolates of $A$. anomala found there, which are believed to originate from a single point introduction (Pinkerton et al., 1998). The question then remains of how these Oregon-resistant accessions would respond when exposed to A. anomala in the eastern United States, where the fungus is native and a greater diversity of isolates would be expected. Shedding some light on this topic, recent greenhouse inoculations as well as field evidence in New Jersey using geographically different isolates of $A$. anomala have shown that some cultivars and selections identified as resistant in Oregon-including 'Gasaway' and some of its offspring - may not hold up to multiple isolates of the pathogen (Molnar et al., 2010a, 2010b). Although more work is needed to better understand the genetic diversity, population structure, and range of pathogenicity within A. anomala, these findings suggest that quarantine efforts to restrict the movement of Corylus material from the East into the Pacific Northwestern United States be maintained to prevent the introduction of new A. anomala isolates. They also suggest it may be necessary to evaluate germplasm in and across the eastern United States to identify sources resistant to a diversity of $A$. anomala isolates.

Furthermore, although historical reports and more recent research provide evidence that native $C$. americana, and to a more limited extent $C$. heterophylla, is tolerant or resistant to EFB (Coyne et al., 1998; Fuller, 1908; Morris, 1920; Weschcke, 1954), these reports are based on anecdotal observations, a limited number of plant accessions assessed in trials, and/or exposure to the pathogen outside of its natural range. Therefore, as efforts increase to breed cultivars with durable EFB resistance and wider adaptation (Molnar et al., 2005), there remains a need to better characterize EFB resistance found within wild Corylus germplasm and existing interspecific hybrids.

In this study, a wide diversity of clonal Corylus accessions, including pure species and various interspecific hybrids of C. avellana, C. americana, C. heterophylla, C. colurna, and $C$. fargesii, were exposed to $A$. anomala in New Jersey over a span of 10 years through field inoculations and by natural spread of the disease. The accessions were obtained from the NCGR, OSU, and the University of Nebraska, Lincoln (UNL) as well as the National Arbor Day Foundation (Nebraska City, NE), the Morris Arboretum (Philadelphia, PA), the Holden Arboretum (Kirtland, $\mathrm{OH}$ ), and private nurseries in Amherst, NY, and Niagara-on-the-Lake, Ontario, Canada. The objectives were to evaluate these accessions for their response to EFB in the field to: 1) compare the EFB response observed in New Jersey with 
that previously reported in Oregon; 2) study wild accessions held in the NCGR and OSU collections that have not been previously exposed to EFB; and 3) validate anecdotal reports and grower observations of resistance in hybrid Corylus selections and cultivars in the eastern United States.

\section{Materials and Methods}

Plant material. Clonal hazelnut material was obtained or purchased from cooperating institutions or nurseries as bareroot dormant layers or scion wood with scion grafting performed at Rutgers University, New Brunswick, NJ. The accessions chosen for study were previously identified as resistant or tolerant to EFB at OSU and/or through grower observations in other regions or were chosen based on anecdotal information suggesting that select clones, Corylus species, or interspecific hybrids (sometimes of unknown parentage) were tolerant of EFB. Known EFB-susceptible cultivars were also included in the trials as controls to assess the presence of EFB on the farm and to later provide a reservoir of inoculum. The plant material evaluated, including species (when known), cultivar name, origin, date of establishment, and number of trees in the field, is presented (Tables 1 and 2). As a point of reference, some general attributes of the species evaluated are also provided in Table 3 and Figures 1 and 2. Grafted plants were propagated in the greenhouse in March of each year using dormant $C$. avellana rootstocks obtained from nurseries in Oregon. Bareroot dormant layers were typically potted in the greenhouse into 3.7- or 7.4-L plastic containers. All plants were grown in a peatbased planting medium (Promix BX; Premier Horticulture, Rivière-du-Loup, Quebec, Canada) and maintained at $24 / 18{ }^{\circ} \mathrm{C}$ (day/night) with 16-h daylengths. Plants remained in the greenhouse until June, when they were moved outside under shade for acclimation before field planting in September or October. Most plants were field planted the same year they were propagated or obtained, although some were held over one additional year before planting. The location of the study was the Rutgers University Vegetable Research and Extension Farm in North Brunswick, NJ. In 2002, a replicated planting was established consisting of 18 trees each of eight accessions found to be resistant to EFB in Oregon as well as the susceptible controls 'Barcelona' and 'Tonda di Giffoni' (Tables 1 and 2). In subsequent years, plantings were smaller as a result of limited available field space and/or propagation wood for grafting. Thus, most other accessions were only represented by one or two trees. Suckers from the base of the grafted trees were removed several times per year, whereas layered trees were allowed to grow naturally with little wood removed from their canopies over the study to allow multiple infection points and to avoid removal of the infected branches needed for disease development and assessment.

EXPOSURE TO EASTERn FILBERT BLIGHT. All plants were exposed to EFB on a yearly basis, which included natural spread of the disease from infected susceptible trees in the trials as well as from adjacent plots containing hundreds of susceptible trees with sporulating cankers. In addition, field inoculations, which consisted of tying infected hazelnut stems into the canopies of the trees each spring, as described in Molnar et al. (2007), were made on nearly all plants annually. Infected stems were collected from susceptible trees growing at the Rutgers University Vegetable Research and Extension Farm.

Evaluation OF DISEASE RESPONSE. In Jan. 2012, a thorough visual inspection for the presence of EFB cankers was carried out (190 accessions for a total of 455 trees) and disease incidence was recorded. On each tree exhibiting EFB, the total number of individual cankers was counted and each canker was measured to calculate the average canker length and the total amount of diseased wood per tree. Branches that were dead at the time of measurement and contained obvious EFB cankers were included in the calculation of the total amount of diseased wood per tree. Then, the total amount of shoot growth (all branches over $2.5 \mathrm{~cm}$ in diameter) per tree was measured and used to calculate each tree's proportion of diseased wood. Of the 18 trees of each of the 10 accessions planted in 2002, disease incidence was recorded for all. Of those accessions expressing EFB, five randomly selected trees were assessed for the canker attributes described previously with results subjected to analysis of variance (PROC MIXED) in SAS (Version 9.2; SAS Institute, Cary, NC). In other cases in which multiple trees of a susceptible genotype were available, averages for the canker attributes were calculated (Table 1).

\section{Results and Discussion}

Corylus aVellana. All trees of known EFB-susceptible accessions, amounting to eight cultivars totaling 50 trees planted over the years 2002 to 2009 developed disease (Table 1). These included 'Tonda di Giffoni' and 'Sacajawea', which express a high level of quantitative resistance to EFB in Oregon (Mehlenbacher et al., 2008; Pinkerton et al., 1993). Besides the known susceptible accessions, the remaining $C$. avellana evaluated here were first described as resistant to EFB at OSU. Of these, 10 accessions remained free of cankers and eight developed EFB. They are discussed in more detail subsequently.

'GASAWAY' AND ITS OFFSPRING. Ten accessions carrying the dominant 'Gasaway' resistance allele, including 'Gasaway' itself, were evaluated in this study. Of these plants, 'Gasaway', VR 20-11, 'Gamma', 'Yamhill', and 'Jefferson' developed EFB, whereas 'Zimmerman', 'Santiam', 'Delta', 'Epsilon', and 'Theta' remained free of disease (Tables 1 and 2). 'Gasaway', VR 20-11, and 'Zimmerman' were included in the 2002 replicated trial (18 trees each) with significant differences observed in their disease incidence and severity. All 18 trees of both 'Gasaway' and VR 20-11 [('Barcelona' × 'Compton') $\times$ 'Gasaway'] developed EFB. Interestingly, the proportion of diseased wood based on five trees of each from the 2002 planting was 0.16 for both accessions. However, the individual and mean canker length differed with average 'Gasaway' cankers $(14.4 \mathrm{~cm})$ shorter than those on VR 20-11 $(22.4 \mathrm{~cm})(P<0.0001)$, suggesting 'Gasaway' is able to restrict the development of EFB to a greater degree than VR 20-11. Non-sporulating cankers attributed to EFB were also observed on both cultivars. They were counted and measured separately, although they were later combined to calculate the averages for canker length, total amount of diseased wood per tree, and the proportion of diseased wood for each tree, because they were causing visible damage, including stem cracking and tissue death. Similar to the typical EFB cankers, the sunken, non-sporulating cankers differed in average length between 'Gasaway' and VR 20-11 at 17.9 and $27.4 \mathrm{~cm}$, respectively. These field results are congruent with earlier greenhouse inoculations with $A$. anomala, in which both accessions developed typical EFB on some trees, although 'Gasaway' was only infected by an isolate from Michigan, expressing typical EFB and sunken, non-sporulating lesions (Molnar et al., 2010a). As a point of comparison, the average 


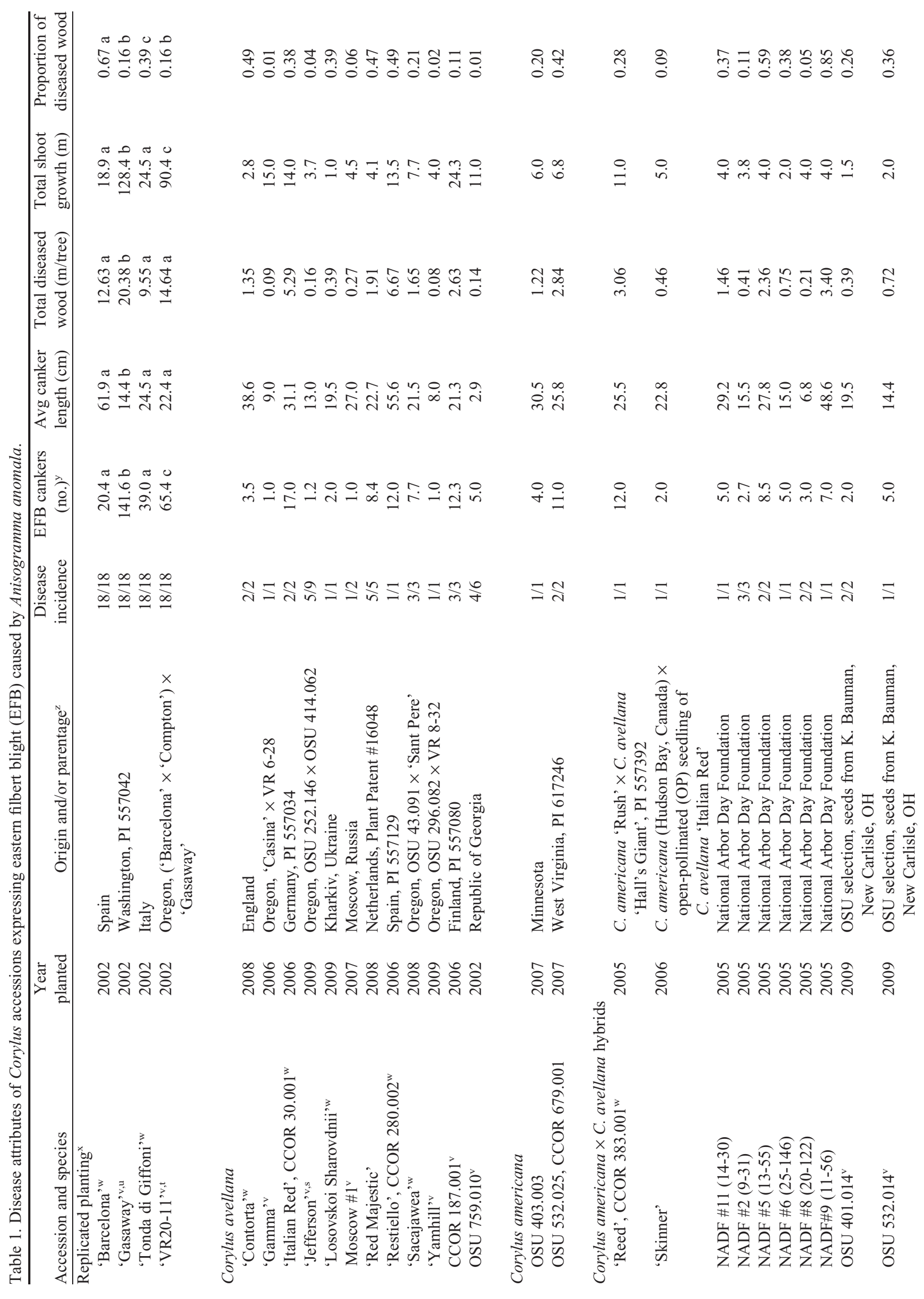




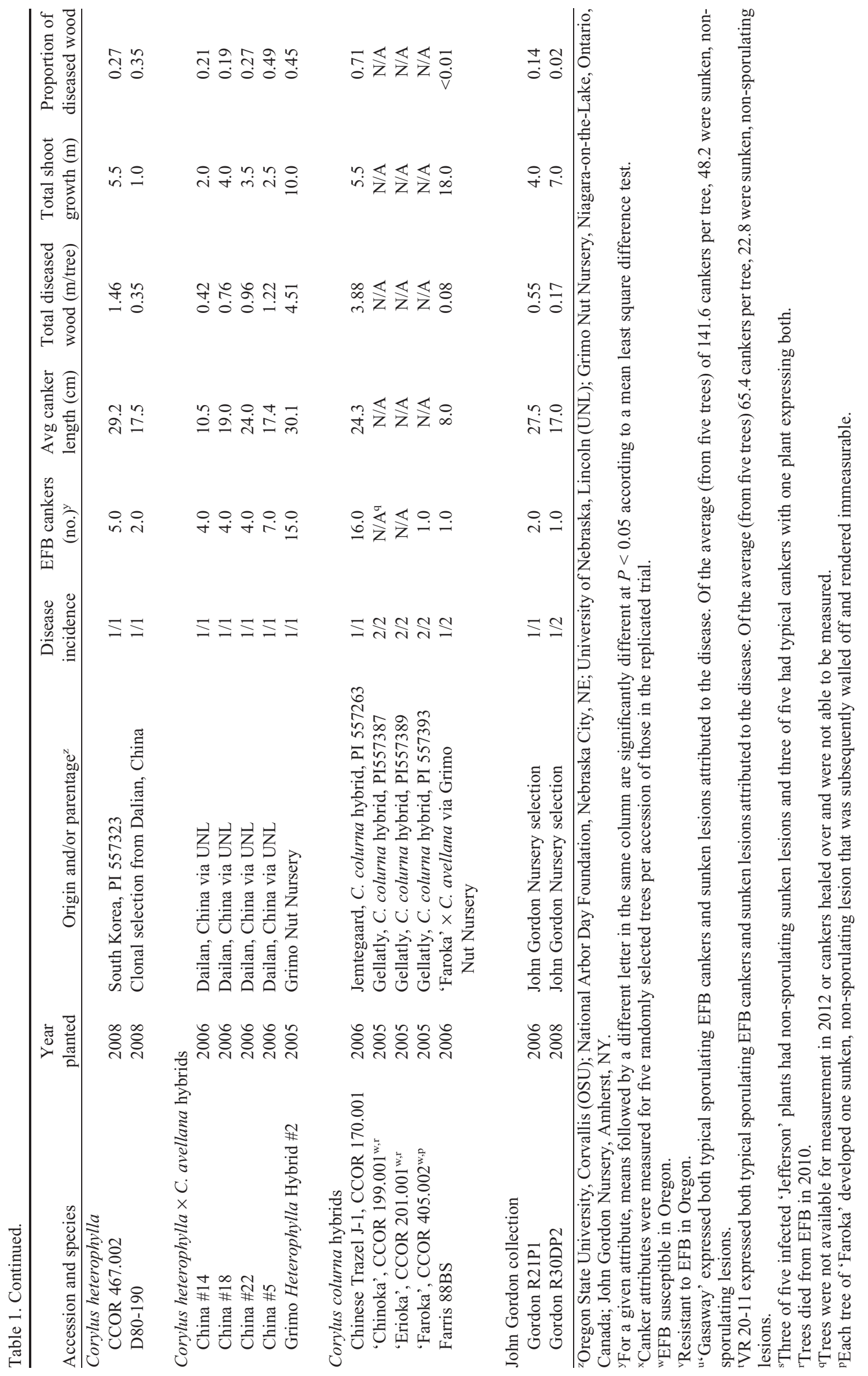


Table 2. Corylus accessions showing no signs or symptoms of infection by Anisogramma anomala.

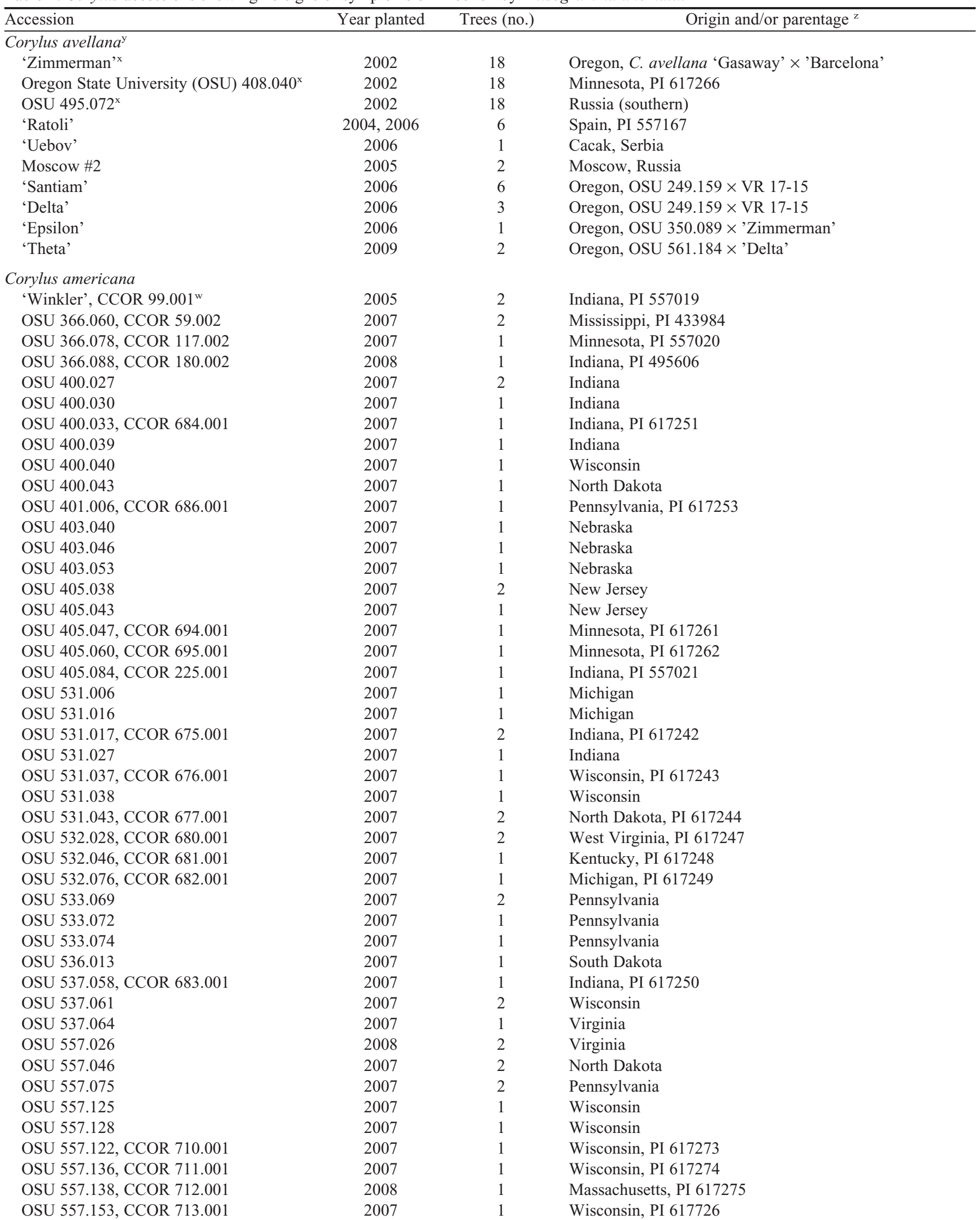


Table 2. Continued.

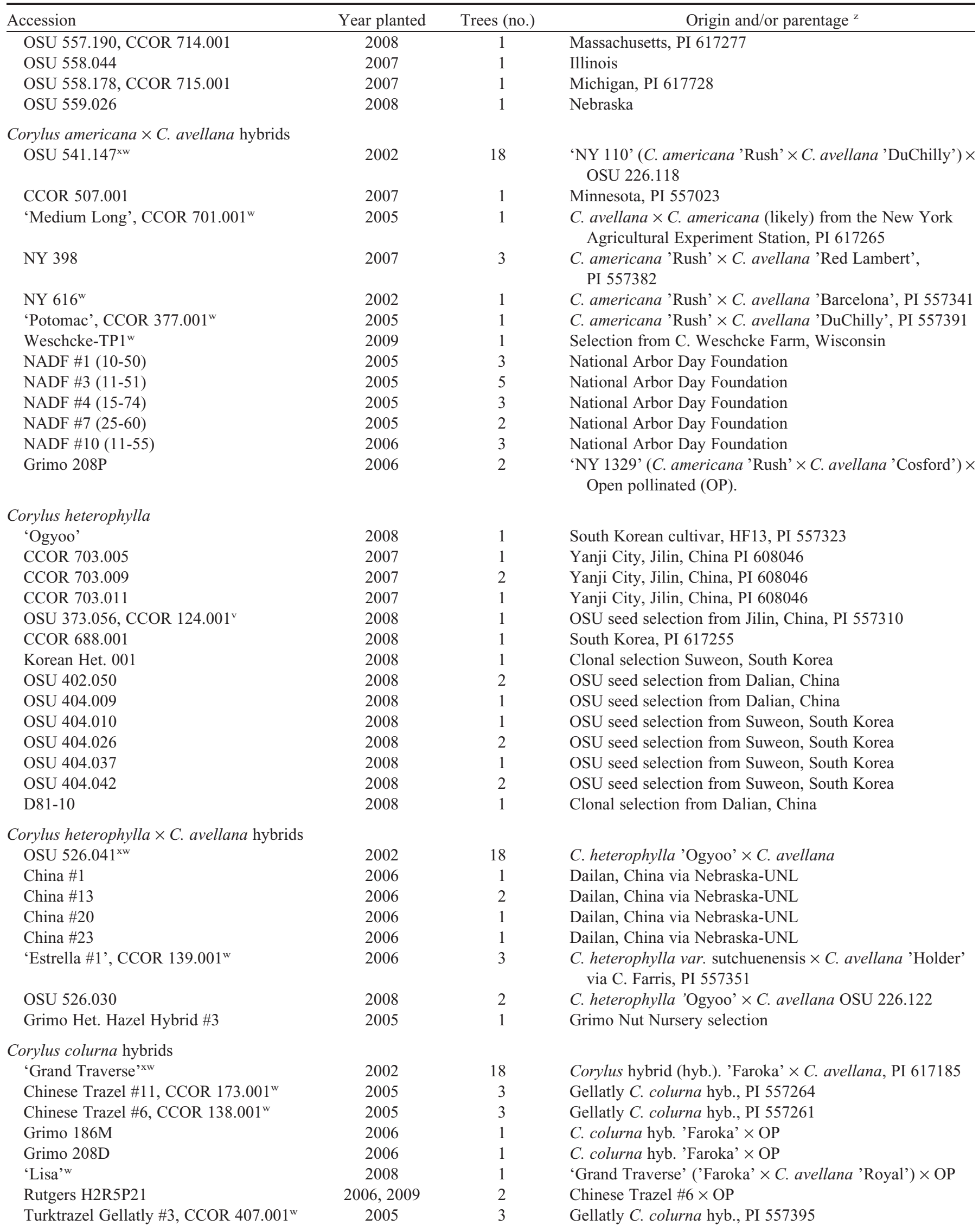

Continued next page 
Table 2. Continued.

\begin{tabular}{|c|c|c|c|}
\hline Accession & Year planted & Trees (no.) & Origin and/or parentage $\mathrm{z}$ \\
\hline \multicolumn{4}{|l|}{ John Gordon collection } \\
\hline 'Auger' & 2007 & 3 & John Gordon Nursery selection \\
\hline 'Slagel' & 2006 & 1 & John Gordon Nursery selection \\
\hline Gordon Neighbor N & 2004 & 1 & John Gordon Nursery selection \\
\hline Gordon R02P1 & 2006 & 1 & John Gordon Nursery selection \\
\hline Gordon R06P2 & 2006 & 1 & John Gordon Nursery selection \\
\hline Gordon R08DP1 & 2006 & 1 & John Gordon Nursery selection \\
\hline Gordon R08DP2 & 2006 & 1 & John Gordon Nursery selection \\
\hline Gordon R09P1 & 2006 & 1 & John Gordon Nursery selection \\
\hline Gordon R10P1 & 2006 & 1 & John Gordon Nursery selection \\
\hline Gordon R10P2 & 2006 & 1 & John Gordon Nursery selection \\
\hline Gordon R15P1 & 2006 & 1 & John Gordon Nursery selection \\
\hline Gordon R15P2 & 2006 & 1 & John Gordon Nursery selection \\
\hline Gordon R16P1 & 2006 & 1 & John Gordon Nursery selection \\
\hline Gordon R17P2 & 2006 & 1 & John Gordon Nursery selection \\
\hline Gordon R17P4 & 2006 & 1 & John Gordon Nursery selection \\
\hline Gordon R18P1 & 2006 & 1 & John Gordon Nursery selection \\
\hline Gordon R22P1 & 2006 & 1 & John Gordon Nursery selection \\
\hline Gordon R24DP1 & 2006 & 1 & John Gordon Nursery selection \\
\hline Gordon R25P1 & 2006 & 1 & John Gordon Nursery selection \\
\hline Gordon R26P1 & 2006 & 1 & John Gordon Nursery selection \\
\hline Gordon R27P2 & 2006 & 1 & John Gordon Nursery selection \\
\hline Gordon R38P1 & 2006 & 1 & John Gordon Nursery selection \\
\hline Gordon R38P2 & 2006 & 1 & John Gordon Nursery selection \\
\hline Gordon R39P1 & 2006 & 1 & John Gordon Nursery selection \\
\hline Gordon R4+5 P2 & 2006 & 1 & John Gordon Nursery selection \\
\hline Gordon R40P3 & 2006 & 1 & John Gordon Nursery selection \\
\hline \multicolumn{4}{|l|}{ Corylus fargesii } \\
\hline C. fargesii 96-574-D Morris & 2004 & 1 & Morris Arboretum, Shaanxi and Gansu provinces, China \\
\hline C. fargesii $96-574-\mathrm{E}$ Morris & 2004 & 1 & Morris Arboretum, Shaanxi and Gansu provinces, China \\
\hline C. fargesii $96-574-\mathrm{F}$ Morris & 2004 & 1 & Morris Arboretum, Shaanxi and Gansu provinces, China \\
\hline C. fargesii $96-574-\mathrm{I}$ Morris & 2004 & 1 & Morris Arboretum, Shaanxi and Gansu provinces, China \\
\hline C. fargesii $96-574-\mathrm{J}$ Morris & 2004 & 1 & Morris Arboretum, Shaanxi and Gansu provinces, China \\
\hline C. fargesii 97-298-C Holden & 2004 & 2 & Holden Arboretum, Shaanxi and Gansu provinces, China \\
\hline
\end{tabular}

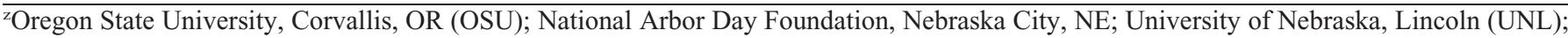
Grimo Nut Nursery, Niagara-on-the-lake, Ontario, Canada; John Gordon Nursery, Amherst, NY; Morris Arboretum, Philadelphia, PA; and Holden Arboretum, Kirtland, $\mathrm{OH}$.

${ }^{y}$ All C. avellana listed were found to be resistant to EFB (EFB) in Oregon.

${ }^{x}$ Included in the 2002 replicated trial.

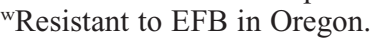

${ }^{v}$ OSU 373.056 was potentially mislabeled at OSU and could be a C. americana selection from Montana. 


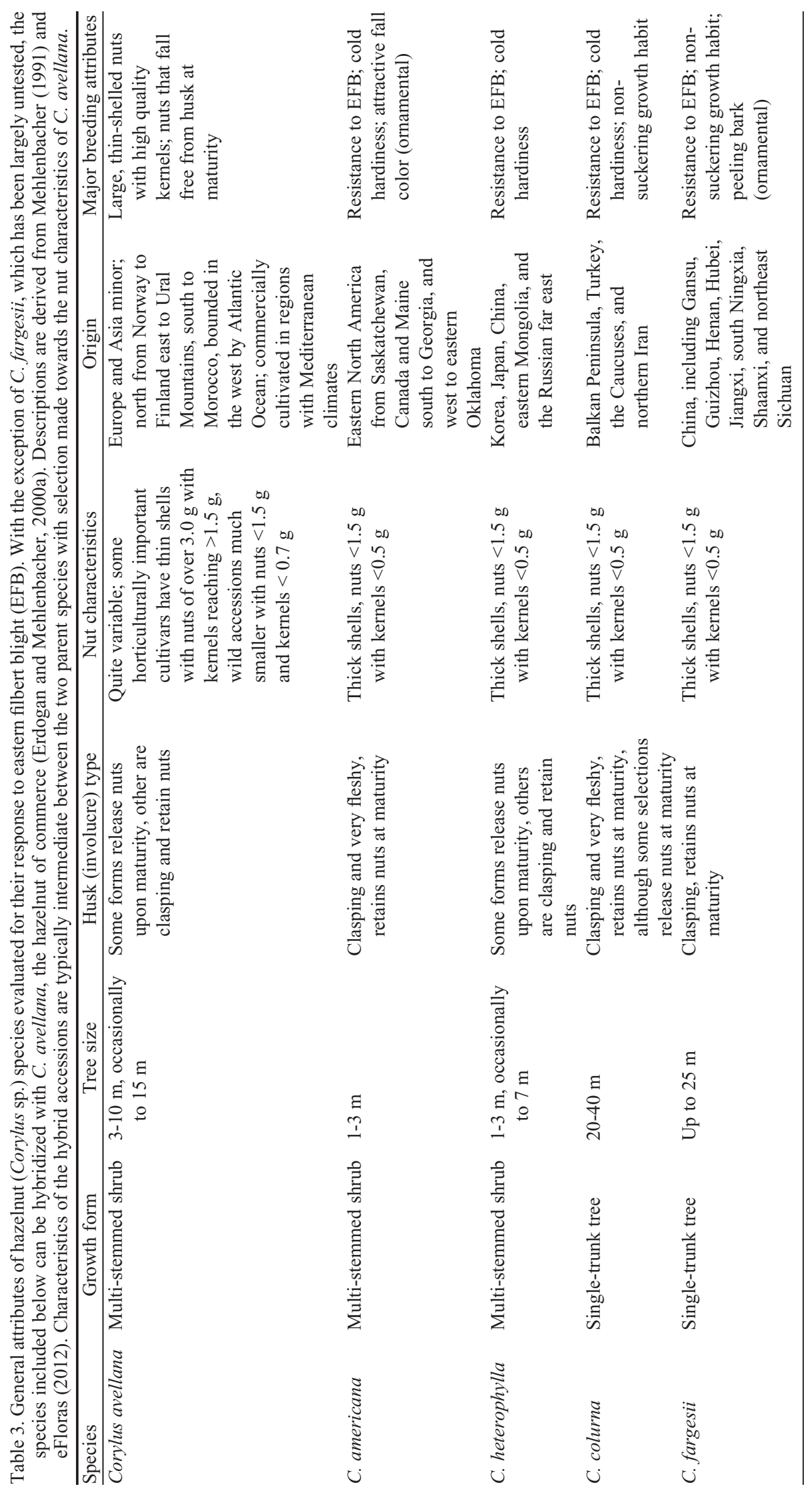




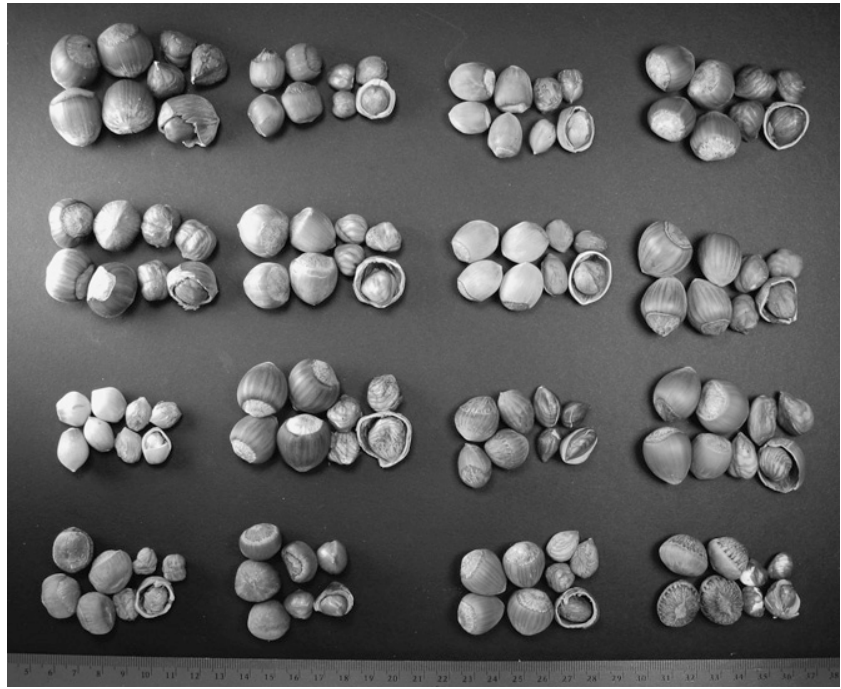

Fig. 1. Representative samples of nuts and kernels of hazelnut (Corylus) species and interspecific hybrids evaluated in this study. Accessions included are as follows (in order from top to bottom, left to right): C. avellana 'Barcelona'; $C$. avellana 'Tonda di Giffoni'; C. avellana 'Gasaway'; C. americana 'Winkler'; C. americana Oregon State University, Corvallis (OSU) 532.076 from Michigan; C. americana $\times C$. avellana hybrid Nebraska \#1 (10-50) C. americana $\times$ C. avellana hybrid NY 398; C. heterophylla OSU 404.026; C. heterophylla $\times C$. avellana OSU 526.041; C. heterophylla var. sutchuensis $\times$ C. avellana 'Estrella \#1'; C. colurna (unnamed seedling selection); C. colurna $\times$ C. avellana 'Faroka'; C. colurna $\times$ C. avellana 'Grand Traverse'; John Gordon Nursery (Amherst, NY) Corylus hybrid (unknown parentage) 'Auger'; John Gordon Nursery Corylus hybrid (unknown parentage) GR10P2; and C. fargesii (seed collected from Morris Arboretum, Philadelphia, PA). A millimeter ruler is located at the bottom of the image to show scale.

canker length and proportion of diseased wood for 'Barcelona' and 'Tonda di Giffoni' from the same 2002 planting was $61.9 \mathrm{~cm}$ and 0.67 and $24.5 \mathrm{~cm}$ and 0.39 , respectively. 'Gasaway' expressed significantly smaller cankers and less proportion of diseased wood than both 'Barcelona' and 'Tonda di Giffoni'. VR 20-11 and 'Tonda di Giffoni' shared a similar average individual canker length, although the proportion of diseased wood of VR 20-11 was considerably less $(P<0.005)$. Despite the presence of many small cankers on each tree of 'Gasaway' and VR 20-11, the level of tolerance appears useful and results in vigorous trees in contrast to 'Barcelona' and 'Tonda di Giffoni' (Table 1). 'Barcelona' and 'Tonda di Giffoni' expressed considerable branch dieback and stem death that halted growth of the plants, whereas 'Gasaway' and VR 20-11 continued to grow vigorously since being planted. No branch dieback or dead stems (over $2.5 \mathrm{~cm}$ ) were observed on any trees of 'Gasaway' and only a minor amount on VR 20-11 (data not shown). We hypothesize, however, that the minor dieback on VR 20-11 may be a contributing factor to the significant difference in average total tree growth between 'Gasaway' and VR 20-11, 128.4 and $90.4 \mathrm{~m}$ $(P<0.003)$, respectively.

Interestingly, 'Zimmerman', a direct descendant of 'Gasaway' ('Gasaway' × 'Barcelona') (Gökirmak et al., 2009; Lunde et al., 2006) represented here by 18 trees also planted in 2002, developed no signs or symptoms of EFB. 'Zimmerman' also remained free of typical EFB after greenhouse inoculations with multiple isolates of $A$. anomala, although one tree developed a sunken lesion when exposed to the Michigan isolate (Molnar et al., 2010a).
Of the pollenizers 'Gamma', 'Delta', and 'Epsilon' (Mehlenbacher and Smith, 2004), all planted in 2006, only 'Gamma' developed EFB, expressed as one small $(9.0 \mathrm{~cm})$ canker. 'Theta', a more recently released pollenizer, remained free of EFB, although it was only planted in 2009. As such, strong conclusions cannot be drawn on its long-term resistance. However, this observation is noteworthy because the results of 'Theta' are in contrast to 'Yamhill' (Mehlenbacher et al., 2009) and 'Jefferson' (Mehlenbacher et al., 2011), also planted in 2009 , in which the one tree of 'Yamhill' and five of nine trees of 'Jefferson' developed EFB (Table 1). These findings are in line with recent reports from Oregon where some trees of 'Jefferson' were observed with very small EFB cankers in an orchard planted adjacent to a highly infected orchard. However, the cankers were described as having few to no sporulating stromata with some walled off by callous tissue in subsequent years (Mehlenbacher et al., 2011; Pscheidt, 2011). Cankers observed here on 'Yamhill' contained typical stromata, whereas cankers on 'Jefferson' contained both typical stromata and non-sporulating sunken lesions.

The variation in disease response between accessions carrying the 'Gasaway' resistance gene, exemplified by the difference between VR 20-11 and 'Zimmerman', suggests that modifying factors, in addition to the major 'Gasaway' allele, may be expressed in some plants that can augment their disease response. These factors have yet to be identified and studied. Similar variation in disease response has been observed in seedlings segregating for the 'Gasaway' resistance allele in field plots at Rutgers University (T.J. Molnar, unpublished data). The ability to visualize the effects of modifying factors in addition to the major gene effect of the 'Gasaway' allele is probably the result of a combination of the high disease pressure and the diversity of $A$. anomala present in New Jersey, a region where the fungus is native. Similar findings have not been reported from Oregon where the diversity of the fungus may be limited (Pinkerton et al., 1998), and where importation of other isolates could be devastating to the commercial hazelnut industry and threaten the world's largest Corylus collections, at the NCGR and at OSU, which contain many valuable but EFBsusceptible cultivars of $C$. avellana.

Eight additional $C$. avellana accessions previously shown to be EFB-resistant in Oregon were evaluated. Five of these remained free of EFB, including 'Ratoli', OSU 408.040, OSU 495.072, 'Uebov', and Moscow \#2. However, Moscow \#1, OSU 759.010, and CCOR 187.001 developed EFB (Table 1).

'Ratoli', a minor cultivar from Tarragona, Spain (Lunde et al., 2000), represented by six trees, remained free of EFB through greenhouse inoculations using multiple isolates of $A$. anomala in a previous study (Molnar et al., 2010a). This cultivar was shown to transmit resistance to its progeny in a manner consistent with a dominant allele at a single locus (Molnar et al., 2009; Sathuvalli et al., 2011b), suggesting its usefulness as a source of resistance in addition to the 'Gasaway' allele. Sathuvalli et al. (2011b) showed that the resistance allele mapped to a different linkage group than that of the 'Gasaway' $R$ gene.

OSU 495.072, represented by 18 trees, was selected at OSU from a seedlot collected in southern Russia in 1989. This accession also developed no EFB cankers after greenhouse inoculation (Molnar et al., 2010a).

OSU 408.040, represented by 18 trees, was selected at OSU from a seedlot received from the University of Minnesota, Minneapolis in 1987 (Chen et al., 2005). Although OSU 

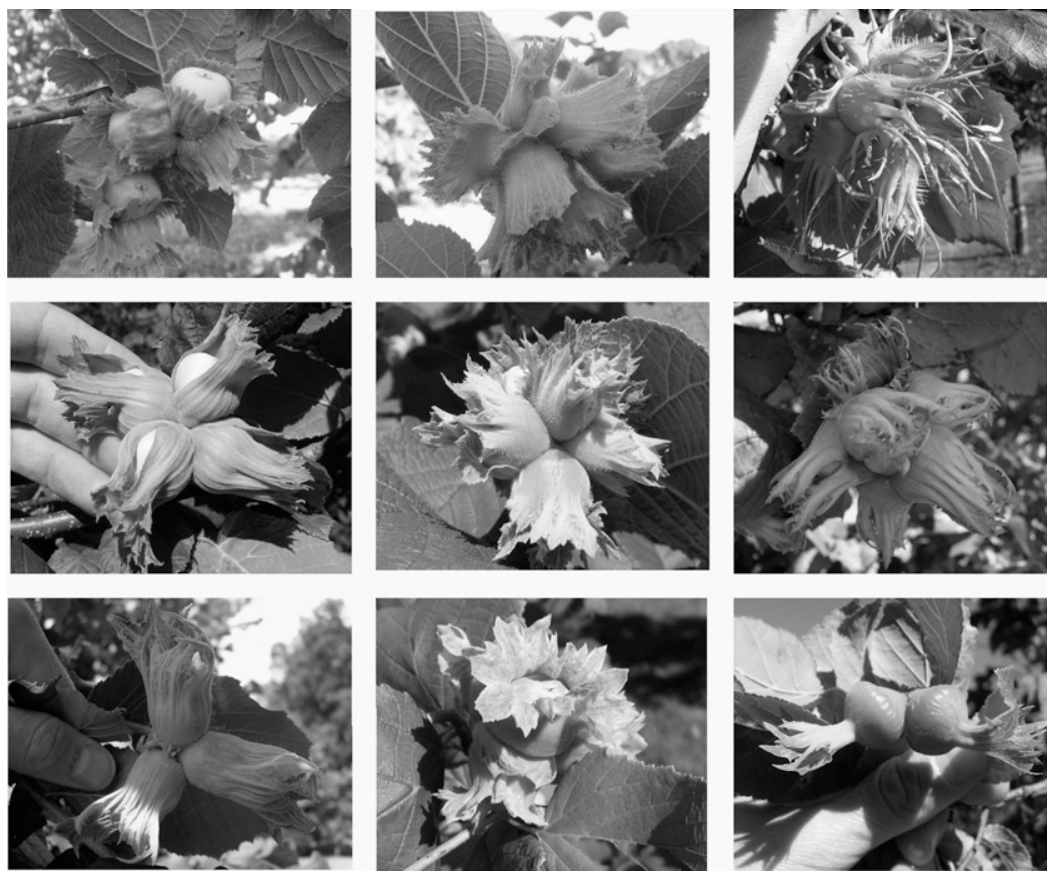

Fig. 2. Example of morphological difference observed in the nut husks (involucres) of the hazelnut (Corylus) species and interspecific hybrids evaluated in this study. Species or hybrid included are as follows (in order top to bottom, left to right): C. avellana (unnamed seedling selection), C. avellana Russian H3R13P40, C. avellana Russian H3R14P26, C. americana (unnamed seedling selection), C. americana $\times$ C. avellana hybrid Nebraska \#1 (10-50), C. heterophylla (unnamed seedling selection), C. colurna (unnamed seedling selection), C. colurna $\times$ C. avellana 'Grand Traverse', C. fargesii (unnamed seedling selection). Pictures were taken in the field in late July 2011 at the Rutgers University Vegetable Research and Extension Farm, North Brunswick, NJ, with the exception of the C. colurna photo, which was taken at the U.S. Department of Agriculture Agricultural Research Service National Clonal Germplasm Repository in Corvallis, OR. The C. avellana pictures were chosen to demonstrate the variation in husk length found in this species. The other images are representative of the species in general. Note that the separate husk images are not to scale and are for comparison of morphological characteristics only. However, for reference, the general range of all the husks shown span 5 to $8 \mathrm{~cm}$ in diameter from the smallest ( $C$. heterophylla) to the largest (C. colurna)

408.040 remained free of EFB in the field trial, it developed a sunken lesion on one tree after greenhouse inoculation with a Michigan isolate of A. anomala (Molnar et al., 2010a).

'Uebov', also developing no EFB, was represented by only one tree planted in 2006 (no greenhouse inoculations were performed on 'Uebov' at Rutgers University). It is a clonal selection from the ARI Fruit and Grape Research Center in Cačak, Serbia (Sathuvalli et al., 2010).

Moscow \#2 is a clonal accession represented by two trees planted in 2005. It originated at the Russian Research Institute of Forestry and Mechanization and was found resistant to EFB through greenhouse inoculations at OSU (Sathuvalli et al., 2010). Interestingly, Moscow \#1, obtained from the same institute and identified as resistant by Sathuvalli et al. (2010), developed EFB on one of two trees in our study.

OSU 759.010 (identical to OSU 759.007) was sent as scions from the Republic of Georgia to OSU. It was later demonstrated that OSU 759.010 passes resistance to its offspring in ratios of 3:1 and 1:1 in Oregon, suggesting resistance stems from a single dominant gene for which OSU 759.010 is heterozygous (Sathuvalli et al., 2011b). In contrast, four of six trees of OSU 759.010 established in the field developed EFB in our study. Similarly, 10 of 19 trees exposed to A. anomala isolates through greenhouse inoculations also developed EFB (Molnar et al., 2010a).
All three trees of CCOR 187.001 planted in 2006 developed EFB. This genotype is a seedling of wild $C$. avellana from Finland. These results are in contrast to the findings of Chen et al. (2007), in which multiple trees of CCOR 187.001 developed no EFB after greenhouse inoculations.

Although a direct comparison may be inappropriate as a result of the different planting dates, Moscow \#1, OSU 759.010, and CCOR 187.001 developed fewer cankers with a lower proportion of diseased wood and less branch dieback than either 'Tonda di Giffoni' or 'Sacajawea', likely indicating a higher level of tolerance to EFB.

Corylus americana. Forty-nine of $51 \mathrm{C}$. americana accessions remained free of EFB (Table 2). These results, based on accessions originating from a wide diversity of geographic origins across the native range of the species in North America, confirm early reports that $C$. americana expresses an innate level of resistance. As early as the 19th century, C. americana was reported as tolerant. Halsted (1892) wrote that on inspection, native hazels were found to show disease "only at rare intervals." Later, Morris (1920) described C. americana as becoming infected with the fungus but not suffering much injury. Similar reports were also made by Fuller (1908), Barss (1930), and Weschcke (1954), supporting the premise that C. americana is highly tolerant of EFB while also acting as a source of inoculum to infect the much more susceptible $C$. avellana when cultivated across its native range. However, no systematic evaluation of C. americana was reported until Pinkerton et al. (1993) included trees of $C$. americana 'Winkler', a wild selection originating from Iowa, in their evaluation of 45 Corylus clones for response to exposure to $A$. anomala in Oregon. In their trial, 'Winkler' displayed no symptoms or signs of EFB, corresponding to the findings in our study for this accession. Later, Coyne et al. (1998) subjected a progeny of C. americana seedlings from Manitoba, Canada, and six accessions from the NCGR collection to greenhouse inoculations with $A$. anomala. Of the 47 seedlings inoculated, only one seedling later showed signs of EFB, whereas two of the six clonal accessions expressed small cankers. These reports, together with our findings that nearly all C. americana accessions remained free of EFB, provide evidence that a high level of resistance exists in the species.

The $C$. americana accessions originated from germplasm holdings of the NCGR and OSU and were not previously evaluated for their response to EFB. Many of the plants are seedling selections made by S.A. Mehlenbacher. These were obtained from wild seed collected across the United States and southern Canada in the 1980s (Sathuvalli and Mehlenbacher, 2011). Improved plants were selected from a larger group of seedlings based on geographic origin, nut characteristics, and yield in the absence of EFB in Corvallis, OR (S.A. Mehlenbacher, personal communication). 
Corylus AMERICANA HYBRIDS. No signs or symptoms of EFB were found on the seven hybrid accessions related to $C$. americana 'Rush', besides 'Reed' ('Rush' $\times C$. avellana 'Halls Giant') (Table 1), which also was found susceptible in Oregon (Lunde et al., 2000). Our results corroborate those of Coyne et al. (1998), who evaluated eight 'Rush' hybrids, including NY 616, and found no EFB after greenhouse inoculation. The hybrid selection Yoder \#5, although not tested here directly, is also believed to trace back to 'Rush' based on simple sequence repeat (SSR) marker analysis (Sathuvalli and Mehlenbacher, 2011). Yoder \#5 was shown by Molnar et al. (2009) to transmit EFB resistance to its offspring in a ratio of one resistant:one susceptible in research plots at Rutgers University. These results further suggest the 'Rush' source of EFB resistance may hold up well in the eastern United States. In addition, NY 398, NY 616, and Grimo 208P [the latter resulting from open pollination of NY 1329 (C. americana 'Rush' $\times$ C. avellana 'Cosford')] have shown no disease in Niagara-on-the-Lake, Ontario, Canada, for many decades in the presence of susceptible plants with EFB cankers (E. Grimo, personal communication).

Besides offspring of $C$. americana 'Rush', the picture of EFB resistance in C. americana hybrids is less clear. 'Skinner', a hybrid of a C. americana seedling from the Hudson Bay area, Canada, crossed with an open-pollinated seedling of (EFBsusceptible) C. avellana 'Italian Red', has been claimed to be EFB-resistant and was propagated and distributed around the eastern United States (Ashworth, 1970). 'Skinner' was susceptible to EFB in our trials and recently in field trials at the UNL (T. Pabst, personal communication).

Six of the 10 National Arbor Day Foundation hybrid accessions evaluated developed EFB cankers. These plants are highyielding selections identified from a large population of seedlings (5000) planted at the Arbor Day Farm in 1996 (Hammond, 2006). They were originally purchased from Badgersett Research Corporation in Canton, MN (Rutter, 1987) and are believed to be advanced-generation hybrids of $C$. americana and $C$. avellana. These accessions were not previously exposed to EFB in Nebraska. Sathuvalli and Mehlenbacher (2011), using SSR markers, showed that most of the Arbor Day accessions evaluated here clustered with $C$. americana 'Winkler'. Their results are logical because 'Winkler' was used extensively by Weschcke (1954) in his breeding efforts. Rutter (1987, 1991) relied heavily on Weschcke's material in establishing plantings at Badgersett Research Farm. Hybrid seedlings from Badgersett have been distributed throughout the midwestern and eastern states with related material now being distributed by the National Arbor Day Foundation.

OSU 401.014 and OSU 532.014 are hybrid accessions selected at OSU, which were derived from open-pollinated seed collected in New Carlisle, $\mathrm{OH}$, although from two distinct sources believed to be unrelated (Sathuvalli and Mehlenbacher, 2011). Their response adds further confusion to understanding inheritance of EFB resistance from C. americana when crossed with $C$. avellana. Both accessions were found to be free of EFB in Oregon trials (S.A. Mehlenbacher, personal communication), but they developed EFB in New Jersey after only two seasons of exposure. In contrast, the hybrid CCOR 507.001, derived from open-pollinated seeds collected from a C. americana (Minnesota) accession in the NCGR collection, remained free of EFB since being planted in 2007.

Our findings support the existing premise that EFB resistance from $C$. americana can be successfully transmitted to offspring when crossed with susceptible $C$. avellana. However, only a limited number of $C$. americana parents (largely 'Rush' and 'Winkler') have been used in past interspecific breeding efforts, and few studies have been conducted to document the inheritance of resistance from the wild species. Although the use of $C$. americana in breeding looks very promising, especially considering its wide native range and adaptation to harsh environments, in addition to EFB resistance, further study is needed to better understand inheritance of EFB resistance, which should include the use of a much wider diversity of wild parents.

Corylus heterophyla. Fourteen of 16 accessions of $C$. heterophylla remained free of EFB (Table 2). Those included in this study represent multiple geographic origins, including northeastern China (Dalian and Yanji City) and central South Korea (Suweon), suggesting resistance to EFB may be a relatively common trait associated with the species. Supporting this idea, a previous report by Coyne et al. (1998) found that all three Korean $C$. heterophylla accessions tested remained free of EFB after greenhouse inoculations. Furthermore, although not a planned part of our clonal study, positive results were also visualized in a population of 66 seedlings planted at Rutgers University in 2007, which were purchased from Lawyer Nursery (Olympia, WA) in 2006 as seed of C. heterophylla collected in China, although information on the geographic origin was not available. The plants were phenotypically C. heterophylla, because all had the conspicuous truncated and variable leaf shape of the species, as described in eFloras (2012), and were very similar in appearance to the $C$. heterophylla accessions obtained from the NCGR. These seedlings were exposed to $A$. anomala over 4 years in the field, and on evaluation in 2012, the group showed a high level of tolerance to EFB with only 14 of 66 expressing cankers, all of which were typically small (less than $20 \mathrm{~cm}$ in length) and caused only minor stem damage (data not shown). Although additional testing of a broader range of germplasm is needed to better understand the resistance in this species, the EFB response of the diverse $C$. heterophylla accessions and the unselected seedlings, along with that reported by Coyne et al. (1998), make a strong case that $C$. heterophylla possesses a high level of tolerance or resistance to EFB despite evolving in a region devoid of $A$. anomala.

Corylus Heterophylla HYBRIDS. Five of the $13 \mathrm{C}$. heterophylla $\times C$. avellana hybrid accessions evaluated in this study developed EFB (Table 1). Of these susceptible plants, four were from a group of eight accessions obtained from the UNL. They were originally imported to the United States from Dalian, China, as dormant rooted layers in 1995 or 1996 by William Gustafson and are believed to be selected hybrids between C. heterophylla and C. avellana (T. Pabst, personal communication). The plants were obtained from the Economic Forestry Institute of Liaoning Province, Dalian, China, where a hybridization and selection program between $C$. avellana and $C$. heterophylla was initiated in the 1980s and is still in operation today (Ming et al., 2005; Weijian et al., 1994). Unfortunately, records were lost at UNL on their identity. However, based on morphological characteristics, the authors are confident of their interspecific hybrid nature. Interestingly, Sathuvalli et al. (2010) also included four C. heterophylla $\times$ C. avellana accessions from Dalian, China, in their greenhouse inoculation study (the relationship between our accessions from UNL is unknown), and all four were found to be susceptible.

OSU 526.041 is the result of a cross made in 1989 of $C$. heterophylla 'Ogyoo' and a mixture of three C. avellana pollens 
(OSU 55.129, Birk 5-6, and OSU 226.122), in which the male parent has yet to be determined. OSU 526.041 was identified as EFB-resistant at OSU (S.A. Mehlenbacher, personal communication). At Rutgers University, trees of OSU 526.041 developed no EFB after greenhouse inoculations with a variety of $A$. anomala isolates (Molnar et al., 2010a), and all 18 trees evaluated in this field study have remained free of EFB since 2002. It should be noted that its parent $C$. heterophylla 'Ogyoo' also expressed no EFB in this study. OSU 526.030, an additional offspring of $C$. heterophylla 'Oygoo' crossed with C. avellana OSU 226.122 ('Tonda Gentile delle Langhe' $\times$ OSU 67.026), has shown no sign of EFB at Rutgers University, although it was established several years later than OSU 526.041 and is represented by only two trees.

'Estrella \#1', from a cross of a selection of $C$. heterophylla var. sutchuensis $\times C$. avellana 'Holder' and selected by Cecil Farris in Michigan (Farris, 1974), showed no sign of disease in this study. 'Estrella \#1' was also found to be resistant in Oregon (Chen et al., 2007). Its sibling, 'Estrella \#2' (Farris, 1974), was found to be susceptible to EFB in Oregon (Chen et al., 2007) and was not included in our study.

Grimo Heterophylla Hybrid \#3 was selected by E. Grimo (Niagara-on-the-Lake, Ontario, Canada) from open-pollinated seed collected from a $C$. heterophylla (possibly hybrid) seedling originating from Quebec in the 1970s. It remained free of EFB in our study. Conversely, Grimo Heterophylla Hybrid \#2, a seedling from the same mother plant, developed EFB. Recent communications with their developer (E. Grimo, personal communication) confirm our EFB response, because the original tree of Hybrid \#3 remains free of EFB in Ontario with Hybrid \#2 later succumbing to the disease. Further evidence of EFB resistance transmitted from $C$. heterophylla in crosses with susceptible $C$. avellana is provided by Coyne et al. (1998). In addition to evaluating pure $C$. heterophylla, they also inoculated select accessions that originated from a cross of $C$. heterophylla 'Ogyoo' (resistant) $\times C$. avellana 55.129 (susceptible). Two of the hybrid selections proved resistant to greenhouse inoculations, whereas the third was susceptible.

Our results from a limited number of accessions support the premise that EFB resistance can be transmitted from $C$. heterophylla selections to some offspring, although the genetic control remains unclear. Regardless, these findings show that C. heterophylla may hold significant potential for breeding for EFB resistance as well as for enhanced climatic adaptation. Corylus heterophylla is native across a wide section of Asia, including very cold parts of northeastern China (Mehlenbacher, 1991). Access to a wider germplasm base and more controlled crosses with select, EFB-resistant $C$. heterophylla parents should lead to further edification concerning the overall genetic resistance of the species.

CORYLUS COLURNA HYBRIDS. Eight of 13 C. colurna hybrids showed no signs or symptoms of EFB (Table 2). Although the results are positive, strong conclusions on the presence of EFB resistance in $C$. colurna cannot be drawn. No pure $C$. colurna accessions were available for evaluation and most of the hybrid plants originated directly or indirectly from the breeding program of J.U. Gellatly in British Columbia, Canada (Gellatly, 1950, 1956, 1964, 1966). This includes the accessions Gellatly Chinese Trazel \#6 (CCOR 138.001) and \#11 (CCOR 173.001) and Gellatly Turkish Trazel \#3 (CCOR 407.001), which, contrary to their names, all appear to be of $C$. colurna descent and were shown to be EFB-resistant in Oregon (Chen et al., 2007). The Rutgers University seedling selection H2R5P21, an open-pollinated seedling of Gellatly Chinese Trazel \#6 originating from seed collected by C.R. Funk at the NCGR in 1995, has also shown no EFB in our plots or in greenhouse inoculations at OSU (S.A. Mehlenbacher, personal communication).

Also included in our study were Gellatly's 'Chinoka', 'Erioka', and 'Faroka'. Two trees each of 'Chinoka' and 'Erioka' were found to be highly susceptible to EFB, dying within 5 years of planting. 'Chinoka' and 'Erioka' were also found to be EFBsusceptible in Oregon (Chen et al., 2007). Interestingly, 'Faroka' became infected with $A$. anomala in Oregon trials where its presence was detected through the use of an enzyme-linked immunosorbent assay after greenhouse inoculations (Lunde et al., 2000) as well as through the visualization of sunken lesions lacking stromata (Chen et al., 2007). Similarly, both trees of 'Faroka' in our trials each exhibited a single sunken lesion lacking stromata, although overall the trees remain very healthy in appearance.

Despite showing evidence of susceptibility to infection by A. anomala, 'Faroka' is believed to have transmitted a high level of EFB resistance to its offspring, 'Grand Traverse' [reported as 'Faroka' $\times$ C. avellana 'Royal' in Farris (1989)]. The male parent of 'Grand Traverse' was disputed in Lunde et al. (2000) based on incompatibility alleles. Eighteen trees of 'Grand Traverse' remained free of EFB in our field study as well as after greenhouse inoculations using multiple isolates of A. anomala (Molnar et al., 2010a). Similar results with 'Grand Traverse' were found at OSU (Lunde et al., 2000) and in Michigan where it was originally developed (Farris, 1995b, 2000). 'Grand Traverse' was also shown to transmit EFB resistance to $\approx 25 \%$ of its progeny in a field trial at Rutgers University (Molnar et al., 2009). 'Lisa', an offspring of 'Grand Traverse', was also found to be resistant to EFB at OSU (Chen et al., 2007) and remains free of EFB in our trials after two seasons of exposure.

Furthermore, 'Faroka' is the female parent of the accessions Farris 88BS, Grimo 208D, and Grimo 186M. The latter two are seedling selections made by $\mathrm{E}$. Grimo derived from the germination of open-pollinated nuts from 'Faroka' (Grimo, 2011). Both Grimo selections remained free of EFB in our trials, whereas $88 \mathrm{BS}$ developed one single EFB canker $(8 \mathrm{~cm})$ on one of two trees after 5 years of exposure.

Chinese Trazel J-1, a hybrid obtained from the NCGR, developed EFB in our trial. It was developed in Oregon in 1972 by O. Jemtegaard (USDA, 2011) and is the only C. colurna hybrid evaluated in this study unrelated to Gellatly material, although the exact background is not known. Our results with the $C$. colurna hybrids suggest the likely presence of heritable EFB resistance in the Gellatly-derived material, especially from 'Faroka'. However, many of the accessions evaluated here were developed through the collection and germination of open-pollinated seeds. Thus, without further work including the use of molecular fingerprinting tools, we cannot be certain that they share a common ancestor or the same EFB resistance genes.

Gordon Corylus HYBrids. Forty of the 42 accessions originating from John Gordon (John Gordon Nursery, Amherst, NY) remained free of EFB. The two infected plants, Gordon R21P1 and R30DP2, developed one typical canker and one sunken lesion, respectively (Table 1). Gordon selected these accessions for our study based on their EFB-free survival for 
many years in his heavily EFB-infected nursery plots. He began his hazelnut breeding/selection efforts in 1963 with the planting of open-pollinated seeds of 'NY 104' (C. americana 'Rush' $\times$ C. avellana 'DuChilly') and 'NY 200' (C. americana 'Rush' $\times$ $C$. avellana 'Hall's Giant') with the objective of selecting improved seedlings. In the 1980s, he added open-pollinated seedlings of Gellatly's C. colurna hybrids 'Faroka', 'Morrisoka', and 'Laroka', as well as the $C$. cornuta $\times C$. avellana hybrid Gellatly 502 (Farris, 1978, 1982; Gellatly, 1950, 1966), to the breeding population, which at one time numbered many thousands of plants. Open-pollinated nuts were then harvested from the best seedlings surviving in his nurseries to plant successive generations for further evaluation. The accessions evaluated here are the result of several generations of selection by Gordon, although their parentage is unknown. Based on Gordon's starting material, it is likely that most of the resistance in the accessions stems from some combination of $C$. americana 'Rush' and the C. colurna $\times$ C. avellana hybrid 'Faroka'. However, the parental origins of these accessions are unknown.

Corylus FARGESII. None of the six C. fargesii accessions developed EFB (Table 2). The scions were collected from healthy trees at the Morris and Holden Arboreta, where EFB was present on nearby $C$. avellana. The original plants were from open-pollinated seed collected by members of the North American China Plant Exploration Consortium in 1996 from Shaanaxi and Gansu provinces in the People's Republic of China (Aiello and Dillard, 2007). Few earlier records of introductions of the species have been reported in the United States besides that of Farris (1995a). Farris (1995a) reported that no symptoms or sign of EFB were observed on his introductions of $C$. fargesii under field conditions in both Michigan and Tennessee for 13 and 8 years, respectively.

\section{Conclusion}

The field response to exposure to A. anomala of 190 clonal Corylus accessions, representing a wide diversity of species and genetic backgrounds, was assessed. From these accessions we identified many that remained free of EFB under very high field disease pressure, where known susceptible accessions succumbed to EFB, including some with known tolerance to infection in Oregon. The diversity of resistant Corylus germplasm should prove useful in developing improved cultivars expressing durable resistance to this disease.

Although additional study is needed to determine the inheritance of resistance when crossing EFB-resistant wild Corylus with susceptible $C$. avellana, the relatively large number of interspecific hybrids remaining free of EFB confirms earlier reports and strongly supports interspecific hybridization as a breeding option. The relatively high interfertility that exists among $C$. avellana, C. americana, and C. heterophylla (Erdogan and Mehlenbacher, 2000a) will facilitate the development of new hybrids, and the diversity of EFB-resistant wild germplasm identified should make a good starting point for further breeding. Although their nuts tend to be smaller and thickershelled than cultivated C. avellana (Fig. 1), the wild species may contribute, in addition to EFB resistance, traits for wider adaptation including extreme cold-hardiness and drought tolerance. For example, $C$. americana is adapted to a very wide region of the United States and southern Canada and some C. heterophylla are adapted to the cold and dry winters of northeastern China. Other Corylus, like the single-trunk tree species
C. colurna, although more challenging to cross with $C$. avellana (Erdogan and Mehlenbacher, 2000a), merit further investigation for breeding EFB-resistant plants that are better adapted to stress, possibly with non-suckering growth habits (Mehlenbacher, 1991; Molnar, 2011).

Furthermore, many of the accessions included in this study are held in the NCGR collection and are freely available for use in research and breeding. The EFB response results from this study will be added to the descriptor data in the National Plant Germplasm System's Germplasm Resources Information (GRIN) database.

Differences in EFB response were found for a number of accessions in New Jersey compared with that reported from OSU, including accessions of $C$. avellana and hybrids. As discussed earlier, these differences can be attributed to the potentially wider diversity of $A$. anomala found in the eastern United States, some of which may express increased virulence (Molnar et al., 2010a) as well as the high disease pressure. These results reinforce the need to maintain the quarantine now in place to restrict the movement of Corylus material from the East into the Pacific Northwestern United States to prevent the introduction of new $A$. anomala isolates. They also demonstrate the usefulness in evaluating germplasm in and across the eastern United States to help identify sources of resistance able to hold up to a diversity of $A$. anomala isolates.

To better verify the resistance of some accessions, longer field evaluations are recommended and will be continued at Rutgers University. Some accessions were only evaluated in the field for 3 years (two seasons of exposure). Although our experience shows this time can be sufficient to suggest tolerance to EFB, longer-term field testing is necessary to reduce the incidence of escapes, to confirm that resistance is stable, and to evaluate levels of tolerance, a component of which includes the annual rate of expansion of the perennial cankers. Regardless, the presence of EFB on plants from only two seasons of exposure is a clear indicator of their susceptibility.

Future studies of the resistant accessions identified or confirmed in this trial include evaluating the genetic relationships using microsatellite (SSR) markers as well as studying transmission of resistance to offspring when crossed with susceptible plants. Many of the accessions have been characterized with SSR markers by Gökirmak et al. (2009), Gurcan et al. (2010), Sathuvalli and Mehlenbacher (2011), and others (GRIN, 2012). However, those of $C$. heterophylla and $C$. colurna origin as well as the accessions from UNL, John Gordon Nursery, and Grimo Nut Nursery have yet to be fingerprinted. Knowing relationships between these plants in addition to their geographic origins and morphological traits could help breeders maintain high genetic diversity in breeding lines as well as helping to distinguish between plants that share a common lineage [and possibly the same EFB resistance gene(s)] or those that are distantly related. Furthermore, work to place identified resistance gene(s) on the hazelnut genetic linkage map (Mehlenbacher et al., 2006) and the identification of closely linked DNA markers [as was done by Sathuvalli et al. (2011a, 2011b) for 'Ratoli' and OSU 759.010] would be of great value to breeding efforts with gene pyramiding a practical option for developing durable EFB resistance. Future research will also include the evaluation of other hazelnut species not included in this study, including C. cornuta, C. californica, C. chinensis, C. jacquemontii, C. ferox, and others, especially as more germplasm from Asia becomes available. 


\section{Literature Cited}

Aiello, A.S. and S. Dillard. 2007. Corylus fargesii: A new and promising introduction from China. Proc. Intl. Plant Prop. Soc. 57: 391-395.

Ashworth, F. 1970. Notes on the less important hardy nuts. Annu. Rpt. Northern Nut Growers Assn. 61:133-136.

Barss, H.P. 1930. Eastern filbert blight. California Dept. Agr. Bul. 19:489-490.

Cameron, H.R. 1976. Eastern filbert blight established in the Pacific Northwest. Plant Dis. Rptr. 60:737-740.

Chen, H., S.A. Mehlenbacher, and D.C. Smith. 2005. AFLP markers linked to eastern filbert blight resistance from OSU 408.040 hazelnut. J. Amer. Soc. Hort. Sci. 130:412-417.

Chen, H., S.A. Mehlenbacher, and D.C. Smith. 2007. Hazelnut accessions provide new sources of resistance to eastern filbert blight. HortScience 42:466-469.

Coyne, C.J., S.A. Mehlenbacher, and D.C. Smith. 1998. Sources of resistance to eastern filbert blight. J. Amer. Soc. Hort. Sci. 124:253257.

Crane, H.L., C.A. Reed, and M.N. Wood. 1937. Nut breeding, p. 827 889. In: Hambidge, G. and E.N. Bressman (eds.). 1937 Yearbook of agriculture. U.S. Govt. Printing Office, Washington, DC.

Davison, A.D. and R.M. Davidson. 1973. Apioporthe and Monchaetia canker reported in western Washington. Plant Dis. Rptr. 57: 522-523.

eFloras. 2012. Flora of China, Corylus. 14 Jan. 2012. <http://www. efloras.org/florataxon.aspx?flora_id=2\&taxon_id=108088>.

Erdogan, V. 1999. Genetic relationships among hazelnut (Corylus) species. PhD diss., Oregon State Univ., Corvallis, OR.

Erdogan, V. and S.A. Mehlenbacher. 2000a. Interspecific hybridization in hazelnut (Corylus). J. Amer. Soc. Hort. Sci. 125:489-497.

Erdogan, V. and S.A. Mehlenbacher. 2000b. Phylogenetic relationships of Corylus species (Betulaceae) based on nuclear ribosomal DNA ITS region and chloroplast matK gene sequences. Syst. Bot. 25:727-737.

Farris, C.W. 1974. An introduction to the stars-A new family of filbert hybrids. Annu. Rpt. Northern Nut Growers Assn. 67:80-82.

Farris, C.W. 1978. The trazels. Annu. Rpt. Northern Nut Growers Assn. 69:32-34.

Farris, C.W. 1982. A progress report on the development of F2 hybrids of Corylus colurna $\times$ C. avellana. Annu. Rpt. Northern Nut Growers Assn. 73:15-17.

Farris, C.W. 1989. Two new introductions: The 'Grand Traverse' hazelnut and 'Spartan Seedless' grape. Annu. Rpt. Northern Nut Growers Assn. 80:102-103.

Farris, C.W. 1995a. The paper barked hazel of China. Annu. Rpt. Northern Nut Growers Assn. 86:76-77.

Farris, C.W. 1995b. The fight to control eastern filbert blight. Annu. Rpt. Northern Nut Growers Assn. 86:73-74.

Farris, C.W. 2000. The hazel tree. Northern Nut Growers Assn., East Lansing, MI.

Food and Agricultural Organization of the United Nations. 2012. Agricultural production, crops primary. $20 \mathrm{Feb}$. 2012. <http://faostat. fao.org/site/567/default.aspx\#ancor>.

Fuller, A.S. 1908. The nut culturist. Orange Judd, New York, NY.

Gellatly, J.U. 1950. Description of filazel varieties. Annu. Rpt. Northern Nut Growers Assn. 41:116-117.

Gellatly, J.U. 1956. Filazels. Annu. Rpt. Northern Nut Growers Assn. 47:112-113.

Gellatly, J.U. 1964. Filazels. Annu. Rpt. Northern Nut Growers Assn. 55:153-155.

Gellatly, J.U. 1966. Tree hazels and their improved hybrids. Annu. Rpt. Northern Nut Growers Assn. 57:98-101.

Germplasm Response Information Network. 2012. Natl. Germplasm Repository, Corvallis, OR, SSR marker data for cultivated hazelnut. 4 Apr. 2012. <http://www.ars-grin.gov/cgi-bin/npgs/crop/evaluation. pl?492825>.
Gökirmak, T., S.A. Mehlenbacher, and N.V. Bassil. 2009. Characterization of european hazelnut (Corylus avellana L.) cultivars using SSR markers. Genet. Resources Crop Evol. 56:147-172.

Gordon, J. 1993. Nut growing Ontario style. Soc. Ontario Nut Growers. Niagara-on-the-Lake, Ontario, Canada.

Grimo, E. 2011. Nut tree Ontario, a practical guide. Soc. Ontario Nut Growers. Niagara-on-the-Lake, Ontario, Canada.

Gurcan, K., S.A. Mehlenbacher, R. Botta, and P. Boccacci. 2010. Development, characterization, segregation, and mapping of microsatellite markers for european hazelnut (Corylus avellana L.) from enriched genomic libraries and usefulness in genetic diversity studies. Tree Genet. Genomes 6:513-531.

Halsted, B.D. 1892. A serious filbert disease. New Jersey Agr. Expt. Sta. Annu. Rpt. 13:287-288.

Hammond, E. 2006. Identifying superior hybrid hazelnut plants in southeast Nebraska. Masters thesis, Univ. of Nebraska, Lincoln, NE. Johnson, K.B. and J.N. Pinkerton. 2002. Eastern filbert blight, p. 44-46. In: Teviotdale, B.L., T.J. Michailides, and J.W. Pscheidt (eds.). Compendium of nut crop diseases in temperate zones. APS Press, Paul, MN.

Johnson, K.B., J.N. Pinkerton, S.A. Mehlenbacher, J.K. Stone, and J.W. Pscheidt. 1996. Eastern filbert blight of european hazelnut: It's becoming a manageable disease. Plant Dis. 80:1308-1316.

Julian, J., C. Seavert, and J.L. Olsen. 2009. An economic evaluation of the impact of eastern filbert blight resistant cultivars in Oregon, U.S.A. Acta Hort. 845:725-732.

Julian, J.W., C.F. Seavert, and J.L. Olsen. 2008. Orchard economics: The costs and returns of establishing and producing hazelnuts in the Willamette Valley. Oregon State Univ. Ext. Serv. Bul. EM 8748-E.

Lunde, C.F., S.A. Mehlenbacher, and D.C. Smith. 2000. Survey of hazelnut cultivars for response to eastern filbert blight inoculation. HortScience 35:729-731.

Lunde, C.F., S.A. Mehlenbacher, and D.C. Smith. 2006. Segregation for resistance to eastern filbert blight in progeny of 'Zimmerman' hazelnut. J. Amer. Soc. Hort. Sci. 131:731-737.

Mehlenbacher, S.A. 1991. Hazelnuts (Corylus), p. 789-836. In: Moore, J.N. and J.R. Ballington (eds.). Genetic resources of temperate fruit and nut crops. Intl. Soc. Hort. Sci., Wageningen, The Netherlands.

Mehlenbacher, S.A., A.N. Azarenko, D.C. Smith, and R.L. McCluskey. 2007. 'Santiam' hazelnut. HortScience 42:715-717.

Mehlenbacher, S.A., R.N. Brown, J.W. Davis, H. Chen, N.V. Bassil, D.C. Smith, and T.L. Kubisiak. 2004. RAPD markers linked to eastern filbert blight resistance in Corylus avellana. Theor. Appl. Genet. 108:651-656.

Mehlenbacher, S.A., R.N. Brown, E.R. Nouhra, T. Gökirmak, N.V. Bassil, and T.L. Kubisiak. 2006. A genetic linkage map for hazelnut (Corylus avellana L.) based on RAPD and SSR markers. Genome 49:122-133.

Mehlenbacher, S.A. and J. Olsen. 1997. The hazelnut industry in Oregon. Acta Hort. 445:337-345.

Mehlenbacher, S.A. and D.C. Smith. 2004. Hazelnut pollenizers 'Gamma', 'Delta', 'Epsilon', and 'Zeta'. HortScience 39:1498-1499. Mehlenbacher, S.A., D.C. Smith, and R.L. McCluskey. 2008. 'Sacajawea' hazelnut. HortScience 43:255-257.

Mehlenbacher, S.A., D.C. Smith, and R.L. McCluskey. 2009. 'Yamhill' hazelnut. HortScience 44:845-847.

Mehlenbacher, S.A., D.C. Smith, and R. McCluskey. 2011. 'Jefferson' hazelnut. HortScience 46:662-664.

Mehlenbacher, S.A., M.M. Thompson, and H.R. Cameron. 1991. Occurrence and inheritance of immunity to eastern filbert blight in 'Gasaway' hazelnut. HortScience 26:410-411.

Ming, X., J. Zheng, L. Radicati, and G. Me. 2005. Interspecific hybridization of hazelnut and performance of five varieties in China. Acta Hort. 686:65-67.

Molnar, T.J. 2011. Corylus, p. 15-48. In: Kole, C. (ed.). Wild crop relatives: Genomic and breeding resources, forest trees. SpringerVerlag, Berlin/Heidelberg, Germany. 
Molnar, T.J., J.M. Capik, and J.C. Goffreda. 2009. Response of hazelnut progenies from known resistant parents to Anisogramma anomala in New Jersey, U.S.A. Acta Hort. 845:73-81.

Molnar, T.J., J.C. Goffreda, and C.R. Funk. 2005. Developing hazelnuts for the eastern United States. Acta Hort. 686:609-618.

Molnar, T.J., J.C. Goffreda, and C.R. Funk. 2010a. Survey of Corylus resistance to Anisogramma anomala from different geographic locations. HortScience 45:832-836.

Molnar, T., J. Capik, S. Zhao, and N. Zhang. 2010b. First report of eastern filbert blight on Corylus avellana 'Gasaway' and 'VR 20-11' caused by Anisogramma anomala in New Jersey. Plant Dis. 94:1265. Molnar, T.J., S.A. Mehlenbacher, D.E. Zaurov, and J.C. Goffreda. 2007. Survey of hazelnut germplasm from Russia and Crimea for response to eastern filbert blight. HortScience 42:51-56.

Morris, R.T. 1915. Notes on the hazels. Annu. Rpt. Northern Nut Growers Assn. 6:36-41.

Morris, R.T. 1920. Hazel nuts. Amer. Nut J. 11:57.

Pinkerton, J.N., K.B. Johnson, S.A. Mehlenbacher, and J.W. Pscheidt. 1993. Susceptibility of european hazelnut clones to eastern filbert blight. Plant Dis. 77:261-266.

Pinkerton, J.N., K.B. Johnson, J.K. Stone, and K.L. Ivors. 1998. Maturation and seasonal discharge pattern of ascospores of Anisogramma anomala. Phytopathology 88:1165-1173.

Pscheidt, J. 2011. 100\% EFB immune? Let's talk! 2011 Growers handbook. Annu. Mtg. Nut Grower Soc. Oregon Washington Brit. Columbia 96:31-34.

Reed, C.A. 1936. New filbert hybrids. J. Hered. 27:427-431.

Rutter, P.A. 1987. Badgersett Research Farm-Plantings, projects, and goals. Annu. Rpt. Northern Nut Growers Assn. 78:173-186.
Rutter, M. 1991. Variation in resistance to eastern filbert blight in hybrid hazels. Annu. Rpt. Northern Nut Growers Assn. 82:159-162.

Sathuvalli, V., S.A. Mehlenbacher, and D.C. Smith. 2010. Response of hazelnut accessions to greenhouse inoculation with Anisogramma anomala. HortScience 45:1116-1119.

Sathuvalli, V., S.A. Mehlenbacher, and D.C. Smith. 2011a. DNA markers linked to eastern filbert blight resistance from a hazelnut selection from the Republic of Georgia. J. Amer. Soc. Hort. Sci. 136:350-357.

Sathuvalli, V.R., H. Chen, S.A. Mehlenbacher, and D.C. Smith. 2011 b. DNA markers linked to eastern filbert blight resistance in 'Ratoli' hazelnut (Corylus avellana L.). Tree Genet. Genomes 7:337-345.

Sathuvalli, V.R. and S.A. Mehlenbacher. 2011. Characterization of American hazelnut (Corylus americana) accessions and Corylus americana $\times$ Corylus avellana hybrids using microsatellite markers. Genet. Resources Crop Evol. (in press).

Slate, G.L. 1961. The present status of filbert breeding. Annu. Rpt. Northern Nut Growers Assn. 52:24-26.

Thompson, M.M., H.B. Lagerstedt, and S.A. Mehlenbacher. 1996. Hazelnuts, p. 125-184. In: Janick, J. and J.N. Moore (eds.). Fruit breeding. Vol. 3. Nuts. Wiley, New York, NY.

U.S. Department of Agriculture. 2011. U.S. Dept. Ag. ARS, National Clonal Germplasm Repository, hazelnut genetic resources, Corvallis, OR. 14 Dec. 2011. <http://www.ars.usda.gov/Main/docs.htm?docid= 11035>.

Weijian, L., X. Ming, D. Defen, and C. Junying. 1994. Genetic improvement of hazelnut for cold hardness and culture. Annu. Rpt. Northern Nut Growers Assn. 85:149-151.

Weschcke, C. 1954. Growing nuts in the north. Webb, St. Paul, MN. 